\title{
A life design-related career development intervention for working adults in the manufacturing, engineering and related sectors
}

\begin{tabular}{|c|c|}
\hline \multicolumn{2}{|c|}{$\begin{array}{l}\text { Authors: } \\
\text { Nicola Taylor }{ }^{1,2} \text { (D) } \\
\text { Chris Beukes }^{3} \text { (D) }\end{array}$} \\
\hline \multicolumn{2}{|c|}{$\begin{array}{l}\text { Affiliations: } \\
{ }^{1} \text { Centre of Research } \\
\text { Excellence, JvR Psychometrics, } \\
\text { Johannesburg, South Africa }\end{array}$} \\
\hline \multicolumn{2}{|c|}{$\begin{array}{l}{ }^{2} \text { Department of Industrial } \\
\text { Psychology and People } \\
\text { Management, College of } \\
\text { Business and Economics, } \\
\text { University of Johannesburg, } \\
\text { Johannesburg, South Africa }\end{array}$} \\
\hline \multicolumn{2}{|c|}{$\begin{array}{l}{ }^{3} \text { South African Career } \\
\text { Development Association, } \\
\text { Pretoria, South Africa }\end{array}$} \\
\hline \multicolumn{2}{|c|}{$\begin{array}{l}\text { Corresponding author: } \\
\text { Nicola Taylor, } \\
\text { nicola@jvrafrica.co.za }\end{array}$} \\
\hline \multicolumn{2}{|c|}{$\begin{array}{l}\text { Dates: } \\
\text { Received: } 21 \text { May } 2019 \\
\text { Accepted: } 28 \text { May } 2019 \\
\text { Published: } 13 \text { June } 2019\end{array}$} \\
\hline \multicolumn{2}{|c|}{$\begin{array}{l}\text { How to cite this article: } \\
\text { Taylor, N., \& Beukes, C. (2019). } \\
\text { A life design-related career } \\
\text { development intervention } \\
\text { for working adults in the } \\
\text { manufacturing, engineering } \\
\text { and related sectors. African } \\
\text { Journal of Career Development } \\
\text { 1(1), a2. https://doi.org/ } \\
\text { 10.4102/ajcd.v1i1.2 }\end{array}$} \\
\hline \multicolumn{2}{|c|}{$\begin{array}{l}\text { Copyright: } \\
\text { (C) 2019. The Authors } \\
\text { Licensee: AOSIS. This } \\
\text { is licensed under the } \\
\text { Creative Commons } \\
\text { Attribution License. }\end{array}$} \\
\hline \multicolumn{2}{|l|}{ Read online: } \\
\hline 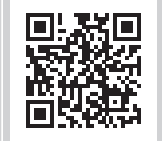 & $\begin{array}{l}\text { Scan this QR } \\
\text { code with your } \\
\text { smart phone or } \\
\text { mobile device } \\
\text { to read online. }\end{array}$ \\
\hline
\end{tabular}

This study examined the potential usefulness of a life design-related career development intervention to enhance the career adaptability of working adults in a business sector most likely to be disrupted by technology and robotics. Participants were employed at a manufacturing workshop in a South African correctional centre. A mixed-methods intervention study design was implemented. The participants completed a number of career-based assessments during the intervention. The results indicated that the participants were well prepared to face the career challenges presented by Industry 4.0 and that the intervention shows promise in improving career adaptability in working adults. More longitudinal research with diverse participants is needed.

Keywords: Group career construction counselling; mixed-methods intervention study; integrated qualitative-quantitative approach; Career Interest Profile; Maree Career Matrix; Career Adapt-Abilities Scale; Self Education Employability Device.

\section{Background}

According to Deloitte's (2019) latest survey on the fourth industrial revolution (Industry 4.0), there is a growing gap in the skills that employees are required to have to face the demands of Industry 4.0. The threat (or promise) of digitalisation and automation means that manual labourers, technicians and artisans may have to learn different skills to remain relevant by functioning as an expert in guiding the activities of robots and other automated processes, rather than doing the work themselves (Deloitte, 2019). This would require reskilling or retraining of the workforce to develop these new skills, which implies a need for a certain readiness on behalf of the workforce to accept a change in the nature of their work.

What is promising is that leaders in organisations are looking to train existing employees rather than hiring new ones when introducing task automation and increased digitalisation into the business. While they do provide training opportunities for their employees, leaders also expect employees to take control of their own career trajectories (Deloitte, 2019). This means that, like it or not, many more people may experience mid-career changes than have ever before. As new types of jobs emerge, so will new career paths, and various sectors of industry may need to prepare for upskilling employees for jobs that have not previously existed. Employees will also need to develop an element of career adaptability to navigate the changes in the new world of work (Savickas \& Porfeli, 2012).

One of the major roles that Sector Education and Training Authorities (SETAs) play in the South African context is to provide education and training opportunities to develop the necessary skills to be able to work in the sector that they represent. One of the SETAs likely to be hard hit by automation is the Manufacturing, Engineering and Related services SETA (merSETA). In its 2015/2016-2019/2020 Strategic Plan, merSETA committed to an '[i]ncreased publication of research products that inform cutting edge solutions in the sector' (merSETA, 2014, p. 35). To meet the demand set by industry, merSETA has set out the following objective: 'Career development, advice and support for the flexible labour market implied by the advent of advanced manufacturing and Industry 4.0 must be put in place to empower current and new entrants manage their career aspirations and development' (merSETA, 2018, p. 58). Subsequently, the merSETA initiated a feasibility study in collaboration with the South African Career Development Association (SACDA) and the University of South Africa (Unisa), termed 'Indigenous Career Management Interventions for Youth and Adults'. 
Up until now, career development interventions implemented by the SETAs have been primarily focused on the youth While youth development is a critical focus area, SETAs have not yet addressed the career development needs of working adults in their various sectors. This study forms part of the merSETA initiative to begin providing possible SETA-supported career development interventions for their organisations in partnership with SACDA. This case study is also part of a larger feasibility study with two main objectives: firstly, to determine the effectiveness of an integrative South African-based career development intervention for employees in the form of a life design-related intervention; secondly, to validate the use of non-psychological instruments that can be used by entry-level Career Development Practitioners (CDPs)

\section{Aim of the study}

The aim of this study is to examine the potential usefulness of a life design-related career development intervention to enhance the career development of working adults in a business sector most likely to be disrupted by technology and robotics.

\section{Method}

\section{Participants and context}

A purposive and criterion sampling was used in the study. The participants consisted of 72 employees in a South African correctional services manufacturing workshop (33 officials and 39 inmates), who participated in a life design career development intervention. They completed the South African version of the Career Adapt-Abilities Scale (CAAS; Maree, 2012), the Maree Career Matrix (MCM; Maree \& Taylor, 2016a, 2016b), the Career Interest Profile (CIP; Maree, 2017a) and the Self Education Employability Device (SEED; Beukes, 2010).

\section{Research design}

A mixed-methods intervention with the implementation of a quantitative and qualitative data construction design was used (qualitative and quantitative data were constructed simultaneously). The CIP and the MCM were used to facilitate the intervention and provide career development guidance to participants. The CAAS was used to test the research hypothesis that the intervention improves career adaptability, while the SEED was implemented to assist individuals in exploring their employability skills.

\section{Instruments}

\section{Career Interest Profile}

The CIP (Maree, 2017a) is a South African-developed career assessment instrument that helps individuals identify: (1) their central career-life themes, (2) their main career-related interests, issues and concerns and (3) their advice from within as to how they can turn issues and concerns into themes of hope that can advance their individual life projects. The CIP is a qualitative (storied or narrative) career-story questionnaire, not a psychological test. Respondents are asked to select five areas of interest that they like and five areas that they dislike from a list of 19 career categories. They also answer a number of self-reflection questions and incomplete sentences. Research indicates that the selection of CIP interests is relatively stable over time, and that the career categories are related as expected to other career interest questionnaires. Being a qualitative assessment instrument that facilitates qualitative career counselling interventions, the CIP does not have psychometric properties as such, but has been demonstrated to be an effective career counselling instrument (Maree, 2017a).

\section{Maree Career Matrix}

The MCM (Maree \& Taylor, 2016a, 2016b) reflects individuals' attraction to 19 job categories by asking them to rate their interest and skill levels in 152 different occupations. The results are then combined and represented on the MCM. The psychometric properties of the MCM were deemed to be acceptable (Maree \& Taylor, 2016a, 2016b), with good reliability and validity evidence.

\section{Career Adapt-Abilities Scale}

The CAAS was developed by Savickas and Porfeli (2012). It is a multi-factorial self-rating measure comprising 24 items (four scales, each with six items) that describe the career adaptability of the individual. The four scales measure concern, control, curiosity and confidence as psychosocial resources for managing transitions, developmental tasks and work traumas. The 24 items make up four subscales used in South Africa by Maree (2012), demonstrating good internal consistency reliability $(\alpha=0.91)$ and satisfactory factor structure.

\section{Self Education Employability Device}

The SEED (Beukes, 2010) is a 60-item self-exploration assessment instrument that can be used to assist individuals in exploring their employability skills. Each item represents a employability skill. The items cluster together to provide feedback on 12 scales relating to employability. The 12 scales measure attitude, service, creativity, barriers, foundation, core, sectors, career, work, goals, network and transitions.

\section{Procedure}

The strategy used in the current study is based on the paradigm and associated strategy explained by Savickas (2011). Career construction counselling (for life design) techniques from different sources and authors were used (Maree, 2015, 2017a, 2017b, 2017c, 2018; Savickas, 2015a, 2015b, 2015c, 2016; Savickas et al., 2009). Two workshops were held in Gauteng in March and April 2019, each lasting 2 days. On day 1, participants began by completing the $C A A S$, followed by completing the CIP, the MCM and the $S E E D$. The administration was supervised by registered psychology professionals. On the afternoon of the first day, career construction counselling-related interaction 
was conducted between the attending psychologist and the different groups, using the power of the audience technique (Di Fabio \& Maree, 2013a, 2013b). Individual groups of participants were given approximately $90 \mathrm{~min}$ to reflect on their career stories in their groups. Thereafter, participants and the psychologist discussed and integrated participants' MCM, CIP and SEED outcomes in the larger group. To facilitate these discussions, the psychologist and participants used an 'Integrated career choice and construction conversation template' to capture their identity, values, themes and interest patterns.

On day two, participants were invited to reflect on their outcomes individually (to the bigger group), while the others (the audience) reflect on prompts by the psychologist and the participant (counsellee) without addressing the counsellee directly. They concurrently self-reflected on the psychologist's questions to the counsellee. This enabled the counsellees to identify not only central career-life themes but also other significant aspects (e.g. values or areas for development) that might emerge through the counsellees' responses to questions in the MCM, CIP and $S E E D$. In addition, counsellees were guided to differentiate between their career interest patterns as revealed by a comparison of the overlap between MCM outcomes in terms of their career interests and confidence, the interest category patterns that emerged from part two of the CIP, as well as the SEED.

Next, the focus shifted to reflections on how to potentially convert painful themes (e.g. never having been 'good enough' in the eyes of others) into themes of hope and of inspiration - all the while advancing their individual careerlife projects. By asking counsellees what they believe they could do to address 'areas for growth' and 'messages' they took from their favourite quotations, and why they regard certain happenings as their biggest successes, they were prompted to draw on their inner advice to themselves to advance their self-awareness, clarify their career identities, choose careers and clarify their unique career-life projects (Di Fabio \& Maree, 2013a, 2013b). Ultimately, career choice and life design-related recommendations were finalised. In addition, based on responses to questions in the CIP and, especially, their reflections on these responses, relevant psycho-educational and psychosocial information was dispensed.

In essence, participants did not only receive 'traditional' career counselling. By acting as audience and soundboard for counsellees' reflections and providing them with a safe space in which they could express themselves unreservedly, they also advanced their fellow counsellees' sense of self, self-awareness and critical consciousness. Sessions were concluded by the completion of each participant's summary of fields for job analysis and, ultimately, his or her vision and mission statement. After the CAAS was administered for a second time, participants were requested to reflect on how they experienced the sessions.

\section{Results}

The assumption checks that were performed found that there were minor issues with normality and some outliers were present within the groups. When working with smaller homogenous samples, violations of the basic assumptions that underlie parametric statistical analyses tend to occur. An effective way of dealing with assumption violations is to use robust statistics because they are not drastically impacted by deviations in assumptions (Erceg-Hurn, Wilcox, \& Keselman, 2013). Robust statistics are reported for the internal consistency reliability coefficients for each instrument.

Participants were asked to rank their five preferred interests on the CIP, which were counted and summed to give an indication of the five most preferred interests. Practicaltechnical was the highest rated interest, with 64 candidates ranking it in their top five interests. This was followed by engineering and the built environment (43); entrepreneurship, running and maintaining a personal business (34); social, caregiving and community services (26) and executive and management practice (23).

Only participants in the first workshop intervention (officials) completed the MCM $(N=32)$. The internal consistency reliability estimates were still all satisfactory for both the interest scales and confidence scales (Table 1). The five highest interest scales for this group were engineering and the built environment; executive and management practices; entrepreneurship; practical-technical; and social, community services and teaching. These are in line with the nature of the work done by the participants and the interests indicated in the CIP. These five also make up the top five confidence scales for the participants.

The internal consistency reliability coefficient for the total CAAS scale was 0.90 (Table 2), which is comparable to the reliability obtained for a previous South African sample (Maree, 2012). The reliability coefficients were acceptable for all subscales, except for curiosity, which was lower than 0.70 for the pre-test, but higher for the post-test. The testretest reliability of the scores was calculated (correlations corrected for attenuation), but we expected them to be lower, as it was expected that scores would change before and after the intervention. There were statistically significant mean score differences before and after the intervention on all scales of the CAAS, except for control (Table 3). The effect sizes were small, with an average increase in scores of one raw score point per subscale, and three raw score points overall.

The internal consistency reliability coefficients for the SEED scales were all satisfactory, apart from the attitude, foundation and fields scales, which fell below 0.65 on both Cronbach's alpha and McDonald's omega values. It is possible that the reliability is lower because of the fact that 
TABLE 1: Internal consistency reliability and descriptive statistics for the Maree Career Matrix $(N=32)$.

\begin{tabular}{|c|c|c|c|c|c|c|c|c|c|c|}
\hline \multirow{3}{*}{$\begin{array}{l}\text { MCM } \\
\text { code }\end{array}$} & \multirow[t]{3}{*}{ MCM scale } & \multirow[t]{3}{*}{ Items } & \multicolumn{4}{|c|}{ Reliability } & \multicolumn{4}{|c|}{ Mean and SD } \\
\hline & & & \multicolumn{2}{|c|}{ Interest } & \multicolumn{2}{|c|}{ Confidence } & \multicolumn{2}{|c|}{ Interest } & \multicolumn{2}{|c|}{ Confidence } \\
\hline & & & $\alpha$ & $\omega$ & $\alpha$ & $\omega$ & $M$ & SD & $M$ & SD \\
\hline $\bar{A}$. & Practical-technical & 8 & 0.814 & 0.816 & 0.822 & 0.823 & 8.47 & 3.91 & 5.47 & 3.56 \\
\hline B. & Practical-creative and consumer science & 8 & 0.809 & 0.811 & 0.829 & 0.830 & 4.47 & 3.10 & 3.56 & 3.29 \\
\hline C. & Musical & 8 & 0.826 & 0.826 & 0.795 & 0.797 & 3.69 & 3.95 & 2.62 & 3.82 \\
\hline D. & Arts and culture & 8 & 0.813 & 0.816 & 0.812 & 0.815 & 4.31 & 3.23 & 2.81 & 3.06 \\
\hline E. & Word artistry & 8 & 0.813 & 0.817 & 0.810 & 0.812 & 3.97 & 3.50 & 2.81 & 3.33 \\
\hline F. & Office work & 8 & 0.822 & 0.822 & 0.825 & 0.826 & 2.78 & 2.73 & 2.66 & 2.77 \\
\hline G. & Marketing & 8 & 0.824 & 0.827 & 0.840 & 0.842 & 5.09 & 3.74 & 4.13 & 3.63 \\
\hline $\mathrm{H}$. & Information and communication technology & 8 & 0.831 & 0.833 & 0.830 & 0.832 & 5.53 & 4.61 & 3.09 & 3.21 \\
\hline I. & Mathematics and/or accounting industry & 8 & 0.825 & 0.827 & 0.816 & 0.820 & 5.75 & 3.79 & 3.72 & 3.20 \\
\hline J. & Social, community services and teaching & 8 & 0.827 & 0.827 & 0.813 & 0.817 & 8.41 & 4.15 & 6.38 & 4.23 \\
\hline K. & Entrepreneurship & 8 & 0.837 & 0.839 & 0.837 & 0.839 & 9.06 & 3.45 & 5.78 & 3.60 \\
\hline L. & Adventure activities, nature and outdoor life & 8 & 0.821 & 0.820 & 0.831 & 0.831 & 7.06 & 3.49 & 5.00 & 2.26 \\
\hline M. & Sport & 8 & 0.838 & 0.840 & 0.834 & 0.836 & 7.03 & 5.18 & 5.44 & 4.38 \\
\hline O. & Medical and paramedical services & 8 & 0.834 & 0.837 & 0.819 & 0.820 & 4.66 & 3.37 & 2.75 & 2.77 \\
\hline P. & Tourism and the air traffic industry & 8 & 0.815 & 0.816 & 0.828 & 0.828 & 5.81 & 3.20 & 4.16 & 2.96 \\
\hline Q. & Legal practice: security diplomatic or civil service & 8 & 0.803 & 0.805 & 0.822 & 0.823 & 6.91 & 3.67 & 5.41 & 2.99 \\
\hline R. & Executive and management practice & 8 & 0.828 & 0.829 & 0.826 & 0.826 & 9.00 & 4.23 & 6.12 & 4.04 \\
\hline S. & Engineering and the built environment & 8 & 0.808 & 0.810 & 0.827 & 0.827 & 10.72 & 3.99 & 7.53 & 3.93 \\
\hline
\end{tabular}

MCM, Maree Career Matrix.

TABLE 2: Internal consistency and test-retest reliability for the scales of the Career Adapt-Abilities Scale $(N=68)$.

\begin{tabular}{|c|c|c|c|c|c|c|c|}
\hline \multirow[t]{2}{*}{$\overline{C A A S}$} & \multirow[t]{2}{*}{ Items } & \multicolumn{2}{|c|}{ Pre-test reliability } & \multicolumn{2}{|c|}{ Post-test reliability } & \multirow{2}{*}{$\begin{array}{c}\text { Pre-post } \\
\text { correlation }\end{array}$} & \multirow{2}{*}{$\begin{array}{c}\text { Test-retest } \\
\text { reliability }\end{array}$} \\
\hline & & $\alpha$ & $\omega$ & $\alpha$ & $\omega$ & & \\
\hline Concern & 6 & 0.811 & 0.818 & 0.826 & 0.830 & 0.422 & 0.515 \\
\hline Control & 6 & 0.797 & 0.799 & 0.798 & 0.799 & 0.472 & 0.482 \\
\hline Curiosity & 6 & 0.637 & 0.640 & 0.717 & 0.719 & 0.360 & 0.532 \\
\hline Confidence & 6 & 0.829 & 0.842 & 0.824 & 0.833 & 0.453 & 0.548 \\
\hline Total career adaptability & 24 & 0.900 & 0.900 & 0.900 & 0.900 & 0.540 & 0.600 \\
\hline
\end{tabular}

CAAS, Career Adapt-Abilities Scale.

TABLE 3: Related samples $t$-test for Career Adapt-Abilities Scale.

\begin{tabular}{|c|c|c|c|c|c|c|c|c|c|}
\hline \multirow[t]{2}{*}{ CAAS } & \multirow[t]{2}{*}{$N$} & \multicolumn{2}{|c|}{ Pre-test } & \multicolumn{2}{|c|}{ Post-test } & \multirow[t]{2}{*}{$d f$} & \multirow[t]{2}{*}{$t$} & \multirow[t]{2}{*}{$p$} & \multirow[t]{2}{*}{$d$} \\
\hline & & Mean & SD & Mean & SD & & & & \\
\hline Concern & 69 & 4.00 & 0.58 & 4.22 & 0.57 & 68 & -2.835 & 0.006 & 0.36 \\
\hline Control & 69 & 4.20 & 0.56 & 4.24 & 0.60 & 68 & -0.438 & 0.663 & 0.05 \\
\hline Curiosity & 69 & 3.85 & 0.62 & 4.01 & 0.52 & 68 & -2.196 & 0.032 & 0.30 \\
\hline Confidence & 69 & 3.98 & 0.57 & 4.16 & 0.65 & 68 & -2.377 & 0.020 & 0.30 \\
\hline Total career adaptability & 68 & 4.01 & 0.45 & 4.16 & 0.49 & 67 & -2.651 & 0.010 & 0.31 \\
\hline
\end{tabular}

CAAS, Career Adapt-Abilities Scale.

TABLE 4: Internal consistency reliability and descriptive statistics for the Self Education Employability Device $(N=68)$.

\begin{tabular}{lccccc}
\hline SEED scale & Items & $\boldsymbol{\alpha}$ & $\boldsymbol{\omega}$ & Item mean & SD \\
\hline Attitude & 4 & 0.588 & 0.573 & 4.02 & 0.55 \\
Creativity & 5 & 0.743 & 0.743 & 3.74 & 0.68 \\
Service & 3 & 0.759 & 0.771 & 3.40 & 0.92 \\
Barriers & 6 & 0.830 & 0.871 & 3.65 & 0.76 \\
Foundation & 4 & 0.594 & 0.640 & 3.91 & 0.64 \\
Core & 12 & 0.851 & 0.853 & 4.08 & 0.51 \\
Sectors & 4 & 0.558 & 0.583 & 3.67 & 0.61 \\
Career & 4 & 0.755 & 0.764 & 4.07 & 0.61 \\
Work & 4 & 0.721 & 0.726 & 3.93 & 0.71 \\
Goals & 6 & 0.813 & 0.813 & 3.87 & 0.64 \\
Network & 4 & 0.759 & 0.763 & 3.69 & 0.72 \\
Transitions & 4 & 0.751 & 0.755 & 3.66 & 0.61 \\
\hline
\end{tabular}

SEED, Self Education Employability Device.

these scales contain only four items each. The content of these scales will be reviewed for future assessments. On average, participants rated the SEED scales relatively high (close to 4.00 for most responses), with the highest average item scores on the core and career scales (Table 4).

\section{Ethical consideration}

Ethical approval for this study was granted by the University of Johannesburg's College of Business and Economics REC (CBEREC18GEN01). Participants were recruited using a firstcome first-serve offer, as there were limited spaces available. Participation was voluntary, and participants were assured that their individual responses would be kept confidential, and that they could withdraw from the study at any time without negative consequences. They continued to receive remuneration while participating in the career workshop, and received a certificate of participation that would add credibility towards inmates' parole applications. All data are stored in secure, access-limited folders and will be anonymised once everything has been collated at the conclusion of the larger study. 


\section{Discussion}

This study represents a response to repeated calls for research on group-based career counselling (see, e.g. Whiston, Li, Mitts, \& Wright, 2017). The aim of the study was to examine the potential usefulness of a life design-related career development intervention to enhance the career development of working adults in a business sector most likely to be disrupted by technology and robotics. The below findings are related to the literature on the influence of group career construction interventions on people's ability to manage changing occupational contexts.

The findings are consistent with the positive outcomes of earlier studies that examined the value of a life design-related intervention using a quantitative and qualitative approach (Di Fabio \& Maree, 2013a, 2013b; Maree, 2019; Rehfuss \& Di Fabio, 2012). The results also align positively with Whiston, Brecheisen and Stephens's (2003) finding that career counselling-related interventions frequently encompass a general counselling component and that a structured group intervention approach seems to yield more effective outcomes than an unstructured approach.

The interests elicited from both the CIP and MCM instruments were very closely aligned. It makes sense that engineering and the built environment and practicaltechnical interests would come to the fore, given the nature of the work that the participants do on a daily basis. What was enlightening was the endorsement of the executive and management practices and entrepreneurship interests. This suggests a desire to either start and run their own business, or to give direction and manage others' activities. There is a need in some sectors in the automotive trade (e.g. panel beating and automotive spray painting) to support the development of small businesses in the industry (Redflank, 2018), and the results of this case study support the assumption that there is at least an appetite for entrepreneurship in the existing workforce. The social, community services and teaching interest was most likely linked to the officials involved in the study who had teaching experience and degrees, and offers an alternative route in the sector for individuals who are passionate about teaching and skills development.

With regard to career adaptability, it was promising that this group of employees scored slightly higher on average on the pre-test on the CAAS (item mean $=4.00$ ) than the South African standardisation sample (item mean $=3.88$; Maree, 2012) and other employed South African adults (item mean = 3.71; Coetzee, Ferreira, \& Shunmugum, 2017). This suggests that this group is well on their way to being ready to face the challenges of Industry 4.0. The lower than desired internal consistency reliability coefficients for the pre-test score on the curiosity scale of the CAAS was corrected in the post-test, and may have been a function of the small sample size. The lower test-retest reliability scores are expected, as career adaptability is intended to improve after such a career intervention. In fact, the differences in scores from the pre-test to post-test are encouraging, as they provide an indication of the success of the intervention in enhancing participants' career adaptability and, consequently, their employability (Savickas, 2019; Urbanaviciute, Udayar, \& Rossier, 2019; Van der Horst \& Klehe, 2019). It would also equip employed adults with an enhanced ability to face the challenges posed by Industry 4.0 to their career path trajectory. The only scale that showed no statistically significant difference in pre- and post-test scores was the control scale, which can be understood given the context and nature of the sample - no matter the intervention, it is unlikely that people would have any greater control over their current circumstances if incarcerated.

In conclusion, it seems plausible to state that the outcomes of the study confirm the findings of Maree (2016a, 2016b), Del Corso and Rehfuss (2011) and others regarding the constructive influence of inspiring feedback during and after an intervention (confirmed by the qualitative findings, which are reported on elsewhere). In addition, the findings provide support for Peng and Chen's assertions (2014) that career construction-related interventions can provide good support to people who lack a sense of purpose in their lives.

In terms of the $S E E D$, it is hypothesised that the higher scores on most items could be because of a lack of understanding of each of the skills. To test this hypothesis, a description of each of the 60 employability skills will be provided together with the context surrounding employability skills. The need for honest answers to ensure a true reflection of current skill levels for the purpose of effective personal development will also be communicated.

\section{Limitations and recommendations for future research}

Results should be interpreted with due circumspection because this was a small, limited study. Moreover, we used a pre-post design without a control group. Future studies should involve larger groups of diverse participants, using quasi-experimental designs (with alternative treatment and no-treatment control groups). In addition, it is essential to conduct regular follow-up to determine the longer term effectiveness and sustainability of the benefits of the intervention to enhance the generalisability of the findings. Other quantitative and qualitative instruments could also be considered in future research. It seems key, too, to assess participants' sense of self, self-worth and career-life identity. Lastly, the development of instruments similar to those used in this study and their implementation in localised and, particularly, in group contexts is essential.

\section{Conclusion}

The results of the first phase of this research project show great promise for the feasibility of the intervention to enhance the career development of working adults in a business sector most likely to be disrupted by technology and robotics. 
The findings also confirm Savickas' (2019) assertion that life design-related intervention revitalises people's suppressed dreams, advances their career adaptability and enables them to convert their pain into hope-filled prospects. While the initial sample is small and limited to a single working environment, preliminary findings indicate that the intervention holds value in enhancing the career adaptability of working adults in the Manufacturing, Engineering and Related (MER) services sector. The psychometric results also show promise for the use of these assessments with workers in skilled trades and related occupations. While this case study is simply a pilot for the larger feasibility study, these early results provide motivation to continue with the project.

\section{Acknowledgements}

The authors would like to thank the project collaboration partners, namely, merSETA, Unisa and SACDA, for supporting this research in the Manufacturing, Engineering and Related services sector, with special thanks to Ms Ester van der Linde for her contribution to the career development profession; Dr Erna Gerryts, Ms Gillian Schultz and Ms Thandeka Langa for facilitating the career development interventions; Mr Brett Gregory and Ms Kerry Martin for data analysis assistance; and the team at JvR Psychometrics for their unfailing support throughout the data collection and capturing processes.

\section{Competing interests}

N.T. is a Director of JvR Psychometrics, which received payment for the use of some of the assessments used in the study, and for the time spent on data collation and analysis. She did not personally benefit from any payment. N.T. is also a statistical editor for the African Journal of Career Development $(A J C D)$. C.B. is the CEO of SACDA, which received funding for the study, but as a non-profit organisation, he does not personally benefit from the funding. He is also a member of the editorial board of the AJCD.

\section{Authors' contributions}

N.T. was responsible for gaining ethical approval, data analysis and the compilation of the case study. C.B. was responsible for project management and the delivery of the intervention, and contributed to the case study write-up and final sign-off.

\section{Funding}

This research was funded by merSETA.

\section{Data availability statement}

The data that support the findings of this study are available on reasonable request from the corresponding author. The data are not publicly available due to the nature of the sample and certain ethical restrictions due to the nature of the data.

\section{Disclaimer}

The views and opinions expressed in this article are those of the authors and do not necessarily reflect the official policy or position of any affiliated agency of the authors.

\section{References}

Beukes, C. J. (2010). Self Education Employability Device. Pretoria: African Skill Framework for Career Management.

Coetzee, M., Ferreira, N., \& Shunmugum, C. (2017). Psychological career resources, career adaptability and work engagement of generational cohorts in the media industry. SA Journal of Human Resource Management/SA Tydskrif vir Menslikehulpbronbestuur, 15(0), a868. https://doi.org/10.4102/sajhrm.v15i0.868

Del Corso, J., \& Rehfuss, M. C. (2011). The role of narrative in career construction theory. Journal of Vocational Behavior, 79(2), 334-339. https://doi.org/10.1016/j. jvb.2011.04.003

Deloitte. (2019). Success personified in the fourth industrial revolution. London, United Kingdom: Deloitte Insights.

Di Fabio, A., \& Maree, J. G. (2013a). Career counseling: The usefulness of the Career Interest Profile (CIP). Journal of Psychology in Africa, 23(1), 41-50. https://doi.org /10.1080/14330237.2013.10820592

Di Fabio, A., \& Maree, J. G. (2013b). Effectiveness of the Career Interest Profile (CIP). Journal of Employment Counseling, 50(3), 110-123. https://doi.org/10.1002/ j.2161-1920.2013.00030.x

Erceg-Hurn, D. M., Wilcox, R. R., \& Keselman, H. J. (2013). Robust statistical estimation. In T. D. Little (Ed.), The Oxford handbook of quantitative methods (Vol. 1, pp. 388406). Oxford, England: Oxford University Press.

Maree, J. G. (2012). Career Adapt-Abilities Scale - South African Form: Psychometric properties and construct validity. Journal of Vocational Behaviour, 80(3), 730-733. https://doi.org/10.1016/j.jvb.2012.01.005

Maree, J. G. (2015). Poverty and life designing. In L. Nota \& J. Rossier (Eds.), Handbook of life design: From practice to theory and from theory to practice (pp. 233-248) Boston, MA: Hogrefe.

Maree, J. G. (2016a). Career construction counselling with a mid-career black male. Career Development Quarterly, 64(1), 20-35. https://doi.org/10.1002/cdq.12038

Maree, J. G. (2016b). How career construction counseling promotes reflection and reflexivity: Two case studies. Journal of Vocational Behaviour, 96, 22-30. https:// doi.org/10.1016/j.jvb.2016.07.009

Maree, J. G. (2017a). Career Interest Profile: Technical Manual (6th edn.). Johannesburg, South Africa: JvR Psychometrics.

Maree, J. G. (Ed.). (2017b). Psychology of career adaptability, employability and resilience. Cham, Switzerland: Springer.

Maree, J. G. (2017c). Utilizing career adaptability and career resilience to promote employability and decent work and alleviate poverty. In J. G. Maree (Ed.), Psychology of career adaptability, employability and resilience (pp. 349-373) Cham, Switzerland: Springer.

Maree, J. G. (2018). Using life design counseling for career construction to facilitate sustainable employability and decent work in a developing country context In V. Cohen-Scali, J. Pouyaud, M. Podgórny, V. Drabik-Podgórny, G. Aisenson, J.-L. Bernaud, I. Moumoula., J. Guichard (Eds.). Interventions in career design and education (pp. 195-214). New York: Springer.

Maree, J. G. (2019). Group career construction counselling: A mixed-methods, intervention study with high school students. Career Development Quarterly, 67(1), 47-61. https://doi.org/10.1002/cdq.12162

Maree, J. G., \& Taylor, N. (2016b). Development of the Maree Career Matrix: A new interest inventory. South African Journal of Psychology, 46(4), 462-476. https:// doi.org/10.1177/0081246316641558

Maree, J. G., \& Taylor, N. (2016a). The Maree career matrix. Randburg: JvR Psychometrics.

Manufacturing, Engineering and Related services Sector Education and Training Authority (merSETA). (2014). Strategic plan for the fiscal years 2015/16 to 2019/2020. Retrieved from http://www.merseta.org.za/Announcements $\% 20$ Docs/merSETA\%20Strategic\%20Plan\%202019_2020.pdf.

Manufacturing, Engineering and Related services Sector Education and Training Authority (merSETA). (2018). Sector skills plan update 2019/2020: Promoting artisan development for employability. Retrieved from http://www.merseta.org. za/Announcements $\% 20$ Docs/merSETA $\% 20$ Sector $\% 20$ Skills $\% 20$ Plan $\% 202019$ 2020.pdf.

Peng, H. \& Chen, M. S. (2014). The study of spirituality, work value and career decision-making between Christian and non-Christian college students. The Journal of Happiness \& Well-Being, 2(1), 63-74. http://www.journalofhappiness. net/frontend/articles/pdf/v02i01/Huiling-1.pdf.

Redflank. (2018). Research study: Labour and skills demand and supply [Research report]. Sandown, South Africa: merSETA.

Rehfuss, M., \& Di Fabio, A. (2012). Validating the future career autobiography as a measure of narrative change. Journal of Career Assessment, 20, 452-462. https:// doi.org/10.1177/1069072712450005

Savickas, M. L. (2011). Career counseling. Washington, DC: American Psychological Association.

Savickas, M. L. (2015a). Career counselling paradigms: Guiding, developing, and designing. In P. J. Hartung, M. L. Savickas, \& W. B. Walsh (Eds.), APA handbook of career intervention (Vol. 1, pp. 129-142). Washington, DC: APA Books. 
Savickas, M. L. (2015b). Life-designing with adults: Developmental individualization using biographical bricolage. In L. Nota \& J. Rossier (Eds.), Handbook of life design: using biographical bricolage. In L. Nota \& J. Rossier (Eds.), Handbook of life design:
From practice to theory and from theory to practice (pp. 135-149). Boston, MA: From practic
Hogrefe.

Savickas, M. L. (2015c). Life-design counseling manual. Retrieved from http://www. vocopher.com

Savickas, M. L. (2016). Reflection and reflexivity during life-design interventions: Comments on career construction counseling. Journal of Vocational Behavior, 97, 84-89. https://doi.org/10.1016/j.jvb.2016.09.001

Savickas, M. L. (2019). Career counseling (2nd edn.). Washington, DC: American Psychological Association.

Savickas, M. L., Nota, L., Rossier, J., Dauwalder, J. P., Duarte, M. E., Guichard, J., ... Van Vianen, A. E. M. (2009). Life designing: A paradigm for career construction in the 21st century. Journal of Vocational Behavior, 75(3), 239-250. https://doi.org/ $10.1016 / j v b .2009 .04 .004$
Savickas, M. L., \& Porfeli, E. (2012). The Career Adapt-Abilities Scale: Construction, reliability, and initial validity of the USA form. Journal of Vocational Behaviour, 80(3), 661-673. https://doi.org/10.1016/j.jvb.2012.01.011

Urbanaviciute, I., Udayar, S., \& Rossier, J. (2019). Career adaptability and employee well-being over a two-year period: Investigating cross-lagged effects and their boundary conditions. Journal of Vocational Behavior, 111, 74-90. https://doi.org/ 10.1016/j.jvb.2018.10.013

Van der Horst, A., \& Klehe, U.-C. (2019). Enhancing career adaptive responses amongst experienced employees: A mid-career intervention. Journal of Vocational Behavior, 111, 91-106. https://doi.org/10.1016/j.jvb.2018.08.004

Whiston, S. C., Brecheisen, B. K., \& Stephens, J. (2003). Does treatment modality affect career counseling effectiveness? Journal of Vocational Behavior, 62(3), 390-410. https://doi.org/10.1016/S0001-8791(02)00050-7

Whiston, S. C., Li, Y., Mitts, N. G., \& Wright, L. (2017). Effectiveness of career choice interventions: A meta-analytic replication and extension. Journal of Vocational interventions: A meta-analytic replication and extension. Journal of 